\title{
Aviation Technology
}

An Example of Collaboration Between Education and Industry

Associate Professor William Gay

University of Cincinnati Clermont College

\section{Initial Concept}

When the University of Cincinnati Clermont College was only in the planning stage, one of the possible technical programs for the new college was a commercial pilot training program. Proximity to the Clermont County airport was certainly a consideration. The airport runway is about 400 feet from the College campus. The airport and the campus were at the center of the state's fastest growing county, Clermont. However, in the College's first years' of operation, nothing was actually done to develop a flight-training program on the campus.

After the College had been in operation nearly twenty years, a program did begin to take shape. This paper is an attempt at chronicling its development. The program is the product of three supporting institutions: Sportsman Market, Inc. (Sporty's), the Clermont County Airport, and the University of Cincinnati Clermont College. The success of the program is dependent upon the resources of all three institutions.

\section{Employment Opportunities}

One of the first steps to be taken in the development of a new technical program is the formation of an advisory committee. Such a committee was formed, and its first task was to determine program need. Employment opportunities as commercial pilots was a prime consideration. Also, of concern was whether there was an institution of higher education in the area offering such a program.

Predicted employment opportunities seemed good for the 1990's and the beginning decade of the next century. Pilots who had been trained by the military for the Vietnam War and later became commercial pilots would be nearing retirement age of sixty. Pilots who reached mandatory retirement age will generate several thousand job openings each year. ${ }^{1}$ The military was making concerted efforts to retain their present pilots due to the high training costs. Thus, the supply of pilots from a peacetime military would be even smaller for commercial aviation. In addition, there were predictions that the aviation industry would continue to grow in both the freight and passenger markets well into the next century. 
Representatives of UC Clermont College, the Dean and the Chair of the Science Mathematics and Engineering Division, approached Mr. Hal Shevers, President of Sportsman's Market (Sporty's) to see if his business would be interested in a cooperative venture into pilot training. In seeking out Sporty's the College was aware that this company, located at the Clermont County Airport, was already providing pilot training as part of its business. Sporty's had a fleet of eight aircraft, which they were using for pilot training purposes. Joseph Vorbeck, Vice President Sporty's Academy, had been Chairman of the General Aviation Flight Technology Section at Purdue University. Joe Vorbeck worked with the Chair of the Science, Mathematics and Engineering Division, Bill Gay (myself), to develop the curriculum. This curriculum had to meet Federal Aviation Administration (FAA) pilot training requirements for private and commercial pilot licenses, and Ohio Board of Regents (OBR) and Clermont College curricular requirements.

The Pilot Training curriculum is a progression of study directed toward training a student in primary, advanced and instrument flight. This curriculum is integrated with two years of college general studies. A special fee is associated with each flight and simulator course. Upon graduation students receive the Associate of Applied Science degree. The student pilots receive 200 to 250 hours of flight and simulator time before completing the Program.

\section{Approval Process}

After the curriculum had been developed, a "Proposal for a New Associate Degree Program" had to be written. This proposal included information on program need, projected costs and revenues, anticipated enrollment, curriculum, course descriptions, and advisory committee activity.

The approval process began with the SME Division (in which the program would reside), the College Curriculum Committee, the Dean, the University, and finally the OBR. The OBR in 1991 formally approved Aviation Technology:Pilot Training Program. The FAA also gave approval of the pilot flight and lecture courses. UC Clermont College enrolled the first freshman class of seven student pilots for the Autumn Quarter of the 1992-93 academic year.

\section{Necessary Facilities and Equipment}

All of the non-flight lecture courses would be offered at the College itself. The flight courses, in which the student pilot is flying a plane, operating the simulator, or being debriefed, would be held at the airport and in regional airspace. All of the training aircraft, and the simulator would be provided by Sporty's. Smaller flight related items, such as maps or textbooks, would be available at the UC Clermont Bookstore or Sporty's Pilot Shop. In short since Sporty's was already providing flight training as a private concern, nearly all of the facilities and equipment were in place. Sporty's did purchase a Frasca flight simulator at program inauguration.

The College was already offering nearly all of the non-flight courses such as mathematics, English and humanities. The only additional lecture courses added to the curriculum were: 
Introduction to Aviation Technology

Pilot Lectures I, II, III, IV, V, and VI

Meteorology

Cockpit Resource Management

Turbine and Piston Engines

Faculty

All faculty teaching the nontechnical course work in the Aviation Program were already in place. The technical course work, namely the aviation related courses, would be taught by a full time instructor whom Sporty's employed. Sporty's paid the salary and benefits of the instructor. The College reimbursed Sporty's for this cost. The College received student tuition and state subsidies for the courses taught. It was agreed by contract between the University and Sporty's that the University-recognized title of "Affiliated Professor" would be given the instructor. This was a non-tenure track position. The instructor was to be selected by a search committee consisting of representatives of Sporty's management and UC faculty and administrative representatives. University, College, Sporty's and FAA criteria were used in the search.

The Pilot Flight courses consisted of one-on-one instruction between the flight instructor and the student pilot. The flight instructors are employees of Sporty's. Presently many of Sporty's flight instructors are graduates of Clermont's own Aviation Program. Some are pursuing baccalaureate degrees on the UC main campus or at other greater Cincinnati area baccalaureate institutions such as Northern Kentucky University. As flight instructors, these graduates can accumulate additional flight hours, which in turn, increases their employability upon graduation from a baccalaureate program.

\section{Recruiting Plans}

Recruiting efforts for the Aviation Program began during the academic year (1991-1992), the year before the startup date for the program. These efforts consisted of letters to area high school graduates, radio and billboard advertisement, communication with high school guidance counselors, and a presence at some area career fairs.

Low enrollments were expected during the first years of the program. This was thought due in part to the high instructional fees and the newness of the program. This was not considered an entirely negative situation. Low enrollment put less stress on flight facilities and personnel such as the number of training aircraft and flight instructors. This allowed Sporty's and the Airport to increase the number of their training aircraft and flight instructors in a gradual and planned fashion. It would also allow Sporty's to recruit the highest quality of flight instructors available.

In the years following the inception of the Aviation Program at Clermont College, recruiting efforts have intensified, and Program enrollments have increased gradually. Program promotion efforts have been the responsibility of both the College and Sporty's. An Aviation Program promotion committee consisting of College and Sporty's representatives determines what efforts will be made, who has what responsibility, what recruiting goals and deadlines are to be, and 
whether these goals are being met.

\section{Program Inauguration}

In September 1992 the first freshman class of student pilots began their course work and flight activities. A kickoff luncheon was held at Sporty's. Those attending, including Ohio Senate President Stanley Aronoff and UC President Joseph Steger, could, as they dined, watch student pilots performing takeoffs and landings on the runway just outside the Sporty's dining room.

\section{Enrollment Patterns}

In developing the Aviation Program proposal, presented to the OBR, we were asked to project enrollments for the first five years of the Program's existence. Below, Table A compares this data with ACTUAL enrollments for the same five-year period.

TABLE A

$\begin{array}{lrrrrrr}\text { ACADEMIC YEAR } & 92-93 & 93-94 & 94-95 & 95-96 & 96-97 & 97-98 \\ \text { PROJECTED ENROLLMENT } & 10 & 23 & 32 & 41 & 45 & \text { * } \\ \text { ACTUAL ENROLLMENT } & 7 & 12 & 13 & 15 & 23 & 30 \\ \text { * no projection made for 1997-98 } & & & & & & \end{array}$

As you can see, ACTUAL ENROLLMENT has been below that which was PROJECTED to OBR. However, it has climbed steadily over this five-year period. As the public becomes more aware of this program, enrollment should continue to increase.

\section{Articulation with Baccalaureate Institutions}

Other factors being equal employment opportunities for pilots are much greater for those holding baccalaureate degrees. Graduates of the Clermont Aviation Program would have an associate degree. Clermont Aviation Program graduates clearly needed the opportunity to transfer into a baccalaureate program. To assure a smooth transfer into a four-year program, an articulation agreement with Embry Riddle Aeronautical University in Daytona Beach, Florida was concluded. Our graduates could then transfer into Embry Riddle's baccalaureate Pilot Training program as juniors.

Many Aviation Program student pilots indicated that they preferred transferring into a four-year program at one of the baccalaureate Colleges of the University of Cincinnati. The UC College of Business Administration (CBA) was the most popular choice. To meet this need Clermont College is presently concluding an articulation agreement with CBA. Both Clermont College's Aviation Technology and Pre-Business curricula were integrated. Upon completion of 
this associate degree Aviation Program graduates will be able to transfer into UC's CBA as juniors.

The integration of the Aviation and Pre-Business curriculum did have one rather glaring shortcoming: Aviation students selecting this option would have to complete 120 quarter-credit hours before enrolling at CBA. This aspect of the Aviation Technology pre-business option required more than six quarters to the Program. No other technical program at the College required as much coursework. Indeed, the other technical programs typically required fewer than 100 quarter-credit hours.

The College of Business Administration suggested that a 12 to 15 credit hour sequence of sophomore pilot training could be repackaged into an upper-division option in operations management. The final offering in the sequence would be a capstone course utilizing case studies and student projects or portfolios. The capstone course also could serve as a student learning assessment tool. As elsewhere student learning and technical program assessments are becoming of greater importance in college accreditation reviews.

CBA wanted assurance that the course content was at the upper-division level. They suggested that we compare our sophomore aviation courses with similar junior-level courses at such baccalaureate institutions as Embry Riddle Aeronautical University, Ohio University, and Bowling Green State University to determine whether some of our sophomore-level courses were comparable to their upper-division courses. With these considerations in mind the following sophomore aviation courses were renamed and given 300-level course numbers:

Commercial Flight Operations and Theory

Comprehensive Aviation Training Theory

Management of Crew Resources

Aircraft Turbine and Piston Engines for Pilots

Capstone course

Thus, aviation students completing their associate degree technical coursework at UC Clermont College, will arrive at CBA with an advanced standing of 15 quarter-credit hours. A graduate of this baccalaureate business degree program with have an associate of applied science degree in aviation technology, a commercial pilot's license (including an instrument rating ), and over 200 hours of accumulated flight and simulator time.

Using the Clermont College - CBA articulation as a model, agreements with other UC Colleges may be negotiated. The UC College of Education, College of Engineering, College of Applied Science, and College of Arts and Sciences are possible parties to articulation agreements with the Aviation Program.

Not all graduates of the Aviation Program may be employed as commercial pilots. With an associate degree in aviation and a baccalaureate degree in an area such as business or engineering, graduates could be employed in aviation related fields such as airport management or aeronautical engineering. Indeed they would be employable in a variety of non-aviation fields as well. 


\section{Future Program Directions}

Improving enrollment in terms of both quantity and quality of students and increasing transfer options are two obvious goals for the Aviation Program. Depending upon student interest and program needs, aviation management might be a possible associate degree major. An avionics major within the Electrical Engineering Technology Program is also under consideration. Cincinnati State Technical and Community College has an associate degree program in Airframe Maintenance. A collaboration between that institution and the Aviation Program might be a possibility. Some of their maintenance course work might be offered at the Clermont Airport or some of their students might be interested in obtaining a private or even commercial pilot's license.

As a partnership between business (Sporty's) and higher education (UC Clermont College), the Aviation Program has worked reasonably well. UC Clermont College relies upon the facilities and expertise of Sporty's to provide the pilot flight training. In turn Sporty's management leaves non-flight instructional issues and responsibilities to UC Clermont. There are areas of mutual concern. Insuring instructional quality, program promotion, faculty selection, student development, financial aid, and graduate placement are a few of these mutual concerns. The leaders of both Sporty's and UC Clermont College have a six-year history of successful collaboration in the development and implementation of this program.

\section{BIBLIOGRAPHY}

1. "Aircraft Pilots." Occupational Outlook Handbook. 1996-1997ed., pp 215-18. 